\title{
Analysis of Transportation Development for Small Islands in Sumenep District, East Java Province
}

\author{
Mohammad Hidayaturrahman ${ }^{1}$ \\ Universitas Wiraraja - Indonesia
}

\begin{abstract}
This study aims to describe the economic potential of islands in Sumenep District. This study uses a qualitative descriptive approach, carried out by collecting data through observation, in-depth interviews, and data tracking. Sumenep District has the largest number of islands in East Java, 287 islands, spread across nine subdistricts. These islands have considerable economic potential, from oil and gas to fisheries, epinephelinae, cromileptes altivelis, and lobster. This area has a great need for the existence of a transportation network as a means of economic mobility of the community, which also affects the price of basic necessities far higher than the area of Sumenep Regency on the mainland, Madura Island and Java Island.
\end{abstract}

Key Words: transportation, small islands, infrastucture

${ }^{1}$ Mohammad Hidayaturrahman, Universitas Wiraraja, Sumenep Indonesia. Email: hidayatsahabatkita2016@ gmail. $\underline{\mathrm{com}}$ 


\section{Analisis Pembangunan Transportasi untuk Pulau-Pulau Kecil di Kabupaten Sumenep, Provinsi Jawa Timur}

Mohammad Hidayaturrahman

\section{Pendahuluan}

Pembangunan nasional, terutama pada era otonomi daerah menghadapi kendala tak sekadar soal pembagian wilayah kekuasaan politik (power), kewenangan (authority), tapi juga terkait dengan pengelolaan (supervision), suatu wilayah yang jaraknya cukup jauh dari wilayah kota kabupaten, termasuk di dalamnya wilayah kepulauan dan daerah terpencil, serta terdepan, terluar, terbelakang. Secara sumber daya, baik dana maupun sumber daya manusia (human resources), daerah memiliki keterbatasan. Pada sisi yang lain, pemerintah pusat meski memiliki banyak sumber daya manusia dan sumber dana, juga tidak begitu mudah mengakses dan menjangkau wilayah-wilayah tersebut (Faqih, 2014: 4).

Terbatasnya infrastruktur, sarana dan prasarana, termasuk sarana transportasi dan komunikasi yang terjadi di wilayah kepulauan menjadi satu persoalan tersendiri yang dihadapi oleh wilayah yang memiliki kekayaan alam (natural resources) sekalipun. Seperti yang terjadi di wilayah Kepulauan Riau. Menurut Sutaryo, dkk, di wilayah Kepulauan Riau minimnya sarana dan prasarana transportasi serta lainnya menyebabkan aksesibilitas di wilayah ini menjadi minim, dan rendah bahkan cenderung terisolasi dari daerah lain yang berada di sekitarnya (Sutaryo, et al., 2015: 111).

Salah satu daerah di Kepulauan Riau yang merasakan betul dampak dari minimnya sarana transportasi adalah Kepulauan Anambas. Transportasi laut dengan kapal, hanya dioperasikan pada saat cuaca sedang bersahabat dan laut tenang. Hal tersebut berdampak kepada aksesibilitas terhadap potensi wisata bahari di Anambas menjadi rendah dan minim. Sehingga sektor pariwisata tidak dapat mendorong peningkatan kesejahteraan warga dan mengurangi kemiskinan (Suryana, 2018: 86).

Hal tersebut juga dihadapi oleh Kabupaten Sumenep yang memiliki wilayah kepulauan yang cukup luas, bahkan paling luas di antara kabupaten lain di Propinsi Jawa Timur. Meski sudah terbilang lebih maju dari pada daerah lain di Indonesia yang juga memiliki wilayah laut dan kepulauan, wilayah kepulauan Kabupaten Sumenep memerlukan kajian mendalam dalam kebijakan pengelolaan sumber daya maritim yang ada. 
Sekadar menyebut contoh, dipisahkannya kelautan dengan perikanan pada dinas terkait, berdasarkan Undang-Undang Nomor 23 Tahun 2014 tentang Pemerintah Daerah dan Keputusan Menteri Kelautan dan Perikanan Nomor 36 Tahun 2016 tentang Organisasi Kementrian dan Kelautan Republik Indonesia menjadi satu hal. Hal lain adalah sengketa pengelolaan dan pendapatan sumber daya alam minyak dan gas (migas), antara Kabupaten Sumenep dengan Provinsi Jawa Timur dalam pendapatan dana bagi hasil (DBH) migas (Bisri, 28 Maret 2013).

Sementara itu, pada sisi pengelolaan transportasi laut di wilayah Kabupaten Sumenep sudah cukup memadai. Kapal yang dioperasikan oleh PT Pelni, BUMD dan pihak swasta serta per seorangan bisa berjalan tanpa ada persoalan berarti di lapangan. Ketersediaan armada kapal sudah cukup. Yang menjadi keinginan warga kepulauan adalah masing-masing kapal beroperasi melayani pulau-pulau yang bisa tersambung dengan kota-kota besar yang terdekat dengan kota kecamatan di kepulauan. Dengan begitu, banyaknya kapal yang ada wilayah kepulauan Sumenep, Jawa Timur bisa menguatkan potensi ekonomi masyarakat pulau, termasuk menjadikan distribusi kebutuhan pokok menjadi lebih lancar, dengan jarak pendek akan lebih murah, dan mempercepat perjalanan komoditas perikanan dari wilayah kepulauan ke kota-kota besar terdekat.

Sehingga, cita-cita pemerintah di bawah kepemimpinan Presiden Joko Widodo dan Wakil Presiden Jusuf Kalla untuk membangun sektor kemaritiman akan berjalan sesuai dengan harapan dan cita-cita bersama. Indonesia yang merupakan salah satu negara maritim yang besar dan kuat, juga mampu meningkatkan kesejahteraan warga, dan mengurangi kemiskinan.

\section{Kajian Teori}

Teori mengenai aksesibilitas untuk wilayah kepulauan menjadi satu pilihan yang dianggap cukup mewakili untuk memotret realitas sosial pembangunan. Menurut Sosilawati, dkk untuk wilayah kepulauan, terlebih lagi bagi wilayah Indonesia yang berada di garis terluar, yang sebagian besar di antaranya memiliki sumber daya alam (natural resources), untuk menunjang kegiatan perekonomian, diperlukan aksesibilitas yang menghubungkan pulau dengan kota induk, atau kota lain yang berdekatan dengan pulau-pulau tersebut (Sosilawati, et al., 2017: 127).

Menurut Simmonds (2001), aksesibilitas dapat disebut sebagai hubungan kedekatan suatu tempat dengan tempat lain, atau suatu daerah dengan daerah lain, 
atau suatu wilayah dengan wilayah lain yang ditandai dengan adanya kemudahan untuk mencapai tujuan dari lokasi asal (Junita, 2016: 2).

Sementara itu, Hurst (1974) mengatakan bahwa aksesibilitas merupakan ukuran dari kemudahan yang terkait dengan sejumlah hal yaitu, waktu, biaya dalam melakukan perpindahan (mobilitas) yang dilakukan oleh orang dari satu tempat ke tempat lain, termasuk juga kawasan dan wilayah dalam sebuah sistem (Magribi \& Suhardjo, 2004: 151).

Bagi Pike (2004), aksesibilitas lebih sering digunakan untuk menggambarkan bagaimana biaya transportasi di suatu daerah, wilayah, kawasan dan lokasi yang sering atau jarang dikunjungi. Semakin sering suatu daerah dikunjungi, maka semakin murah biayanya, namun sebaliknya, semakin jarang suatu daerah dikunjungi, biasanya biaya yang dibutuhkan akan lebih mahal (Wahdiniwaty, 2011: 201).

Litman (2016) menyebut aksesibilitas sebagai alat untuk mengukur potensi saat orang melakukan suatu perjalanan. Selain itu, aksesibilitas juga digunakan untuk menghitung jumlah perjalanan itu sendiri. Ukuran tersebut dapat digunakan untuk menggabungkan sebaran geografis tata guna lahan dengan kualitas sistem jaringan transportasi yang menghubungkannya. Dengan demikian, menurut Litman, aksesibilitas dapat digunakan untuk melihat kemudahan untuk mencapai suatu tempat (Kuswati \& Herawati, 2017: 55).

Pada tataran konsep, aksesibilitas mencakup sejumlah unsur yang terangkum dalam sejumlah kata yaitu mobilitas/perpindahan, wilayah, kemudahan, transportasi, waktu dan hubungan. Sehingga jika dapat disebut bahwa aksesibilitas terwujud jika mobilitas orang pada satu wilayah dengan sangat mudah dilakukan dengan transportasi yang ada, dengan waktu yang lebih efektif dan efesien, sehingga satu wilayah dengan wilayah lain saling terkait, tersambung dan memiliki hubungan yang dapat memudahkan masing-masing orang di wilayah tersebut untuk memenuhi kebutuhan hidup.

\section{Metode}

Metode penelian ini menggunakan pendekatan deskriptif kualitatif, yang secara khusus mengkaji potensi ekonomi yang ada di wilayah kepulauan Kabupaten Sumenep, Jawa Timur. Pengumpulan data dilakukan dengan pengamatan langsung (observasi) ke berbagai wilayah kepulauan. Selain observasi, pengumpulan data juga dilakukan dengan melakukan wawancara mendalam (indepth interview) dengan 
beberapa informan yang terkait langsung dengan persoalan yang sedang diteliti. Nara sumber yang diwawancarai cukup beragam, mulai dari pihak pemerintah, tokoh masyarakat, pelaku usaha, dan kelompok lain yang mengetahui persoalan yang ditanyakan. Data yang diperoleh kemudian ditambah dengan data yang ada di dinas terkait, maupun berbagai literatur daring maupun luring. Secara keseluruhan penelitian ini cukup komprehensif untuk memotret fenonema di wilayah kepulauan Sumenep, Jawa Timur.

\section{Hasil dan Pembahasan}

Secara geografis, Kabupaten Sumenep, Jawa Timur merupakan wilayah yang terdiri dari daratan dan kepulauan. Di antara empat kabupaten yang ada di Pulau Madura, Kabupaten Sumenep memiliki wilayah yang paling luas. Luasnya wilayah Kabupaten Sumenep disebabkan oleh wilayah lautan yang terbentang, hingga berbatasan dengan beberapa propinsi lain di Indonesia. Di ujung timur wilayah Kabupaten Sumenep ada Pulau Sakala, Kecamatan Sapeken yang berbatasan dengan wilayah Sulawesi Selatan. Di ujung utara ada Pulau Karamian, Kecamatan Masalembu. Posisi Pulau Karamian berbatasan dengan wilayah Kalimantan Selatan. Jarak Pulau Karamian ke Kalimantan Selatan lebih dekat daripada jarak ke Kota Sumenep. Satu lagi wilayah Kabupaten Sumenep yang berbatasan dengan propinsi lain, yaitu Pulau Sepanjang, Kecamatan Sapeken. Pulau Sepanjang lebih dekat ke Propinsi Bali daripada ke Kota Sumenep. Luas wilayah Kabupaten Sumenep jauh melampaui wilayah tiga kabupaten lain di Madura seperti Kabupaten Pamekasan, Sampang dan Bangkalan. Bahkan jika ketiga kabupaten tersebut digabungkan, luas wilayahnya tidak akan mengalahkan wilayah Kabupaten Sumenep, terutama karena adanya wilayah kepulauan yang terbentang dari Karamian, Sakala, hingga Sepanjang.

Jumlah pulau yang ada di Kabupaten Sumenep sebanyak 126 pulau, baik pulau kecil maupun besar, yang berpenduduk maupun yang tidak berpenduduk. Pulau-pulau tersebut tersebar secara luas di sembilan kecamatan yang masuk wilayah Kabupaten Sumenep, Jawa Timur. Pulau terdekat adalah Pulau Poteran, yang masuk wilayah Kecamatan Talango, dan yang terjauh adalah Pulau Karamian yang masuk wilayah Kecamatan Masalembu. Sembilan kecamatan yang berada di wilayah Kabupaten Sumenep, yaitu Talango, Giligenting, Nonggunong, Gayam, Raas, Masalembu, Arjasa, Kangayan, Sapeken. 


\subsection{Sumber Daya Alam Migas}

Wilayah kepulauan Kabupaten Sumenep, Jawa Timur memiliki potensi kekayaan alam yang cukup besar. Salah satu potensi kekayaan alam yang saat ini telah dimanfaatkan adalah minyak dan gas (migas). Seluruh perusahaan migas yang saat ini berproduksi, merupakan perusahaan yang berlokasi di wilayah kepulauan Sumenep, baik yang berada di lepas pantai (offshore) maupun yang berada di daratan (onshore). Gas tersebut dialirkan ke perusahaan dan pusat industri di Sidoarjo, Surabaya dan Gresik, Jawa Timur (Kahir, 2018).

Dari tiga perusahaan migas yang telah berproduksi atau akan berproduksi dalam waktu dekat ini yang berada di wilayah kepulauan, masing-masing adalah Kangean Energy Indonesia (KEI) yang berada di Pulau Pagerungan, Kecamatan Sapeken, Kabupaten Sumenep, telah berproduksi sejak tahun 1993 lalu. Sejak 2012 lalu KEI juga telah berproduksi di sumur baru yang berada di wilayah perairan Pulau Komirian, Kecamatan Raas, Kabupaten Sumenep yang dikenal dengan sumur Terang Sirasun Batur (TSB). Selain itu, ada pula PT Santos yang berproduksi di Blok Maleo, yang merupakan wilayah perairan Pulau Gili Raja, Kecamatan Gili Genting, Kabupaten Sumenep, berproduksi sejak 2007. Terakhir, Husky CNOOC Madura Limited (HCML) mengelola Blok MDA-MBH yang berada sekitar $10 \mathrm{KM}$ di sebelah selatan perairan Sepudi dan Raas, Kabupaten Sumenep, akan berproduksi pada 2019.

\subsection{Potensi Perikanan Melimpah}

Wilayah kepulauan Sumenep, Jawa Timur memiliki potensi kekayaan perikanan laut yang cukup besar. Hal ini memungkinkan karena Kabupaten Sumenep memiliki wilayah laut dan perairan yang paling luas di Jawa Timur. Wilayah laut dan perairan Kabupaten Sumenep di sebelah utara berbatasan dengan Kalimantan Selatan, sementara sebelah timur berbatasan dengan Sulawesi Selatan dan sebelah selatan berbatasan dengan Bali. Wilayah laut dan perairan Kabupaten Sumenep memiliki potensi perikanan yang luar biasa banyak. Tak heran jika banyak nelayan dari luar Sumenep, di Madura, seperti Pamekasan, dan dari Jawa Timur seperti Lamongan serta Pati, Jawa Tengah yang datang ke wilayah kepulauan Sumenep untuk menangkap ikan.

Potensi perikanan yang berada di wilayah laut di kepulauan Kabupaten Sumenep, Jawa Timur seperti ikan tongkol, tengiri dan layang, yang bisa didapatkan oleh nelayan sepanjang tahun. Selain ikan tersebut, terdapat sejumlah jenis ikan yang bernilai ekonomi tinggi, seperti kerapu dan lobster yang diekspor ke luar negeri 
melalui Bali (Wawang, 2018).

Selain ikan, Kabupaten Sumenep juga memiliki potensi rumput laut yang luar biasa besar. Bahkan, Kabupaten Sumenep memiliki wilayah yang masuk Minapolitan dengan komoditas keunggulan, yaitu rumput laut. Potensi rumput laut di wilayah Kabupaten Sumenep tersebar di sejumlah kecamatan, yaitu Kecamatan Sapeken, Kangayan, Arjasa, Saronggi, Bluto, Giligenting, Raas, Talango dan Batu Putih. Luas lahan yang selama ini dijadikan budidaya rumput laut 243 ribu hektar, dengan hasil produksi 549 ribu ton rumput laut basah dan 91 ribu ton rumput laut kering per tahun (Kominfo Jatim, 8 Maret 2013).

\subsection{Sapi Sepudi Berlayar Hingga Kalimantan}

Wilayah kepulauan Kabupaten Sumenep, khususnya Pulau Sepudiyang terdiri dari dua kecamatan, yaitu Kecamatan Gayam dan Nonggunong memiliki potensi peternakan sapi dengan ras asli Madura di Jawa Timur. Meski tidak ada data pasti yang menunjukkan berapa jumlah populasi sapi di Pulau Sepudi, namun dapat ditemukan secara langsung, setiap rumah atau keluarga di Pulau Sepudi pasti memiliki peternakan sapi. Sedikitnya, setiap keluarga memiliki dua ekor sapi yang dipelihara di dalam kandangkhususyangberadadibagianbelakangrumah,terpisahdarirumahpemiliknya.

Sapi yang dimiliki oleh peternak sapi di Pulau Sepudi setiap harinya dikirim ke sejumlah wilayah di Indonesia dengan menggunakan perahu tradisional. Wilayah yang menjadi sasaran distribusi sapi-sapi dari Pulau Sepudi adalah wilayah Kalimantan, dikirim melalui Banjarmasin, Kalimantan Selatan. Pengiriman sapi dari Pulau Sepudi ke Banjarmasin sudah berlangsung sejak lama dan turun-temurun, bahkan jauh sebelum perahu menggunakan mesin motor, saat hanya menggunakan layar.

Selain ke Kalimantan, sapi dari Sepudi juga dikirim ke berbagai wilayah di Jawa. Pintu masuk distribusi sapi Sepudi ke Pulau Jawa adalah Pelabuhan Kalbut, Situbondo. Dari titik tersebut, sapi-sapi asal Sepudi kemudian didistribusikan ke berbagai wilayah di Jawa Timur, Jawa Tengah, Jawa Barat dan Jakarta. Sapi yang berasal dari Pulau Sepudi diangkut menggunakan perahu motor tradisional. Para pedagang sapi yang mengirim sapi ke Situbondo memiliki kebiasaan unik, yaitu menceburkan sapi ke laut, untuk kemudian digiring ke daratan dengan selamat, tanpa tenggelam. Sapi dari Pulau Sepudi setiap dua kali dalam satu pekan dikirim ke Pulau Madura, melalui Pelabuhan Dungkek, Sumenep. Dua hari tersebut bersamaan dengan pasaran sapi yang berlangsung setiap hari Senin dan Kamis. Dulu 
pasaran sapi di Sumenep dipusatkan di Pasar Bangkal, kemudian dipindah Bluto.

Besar harapan warga Pulau Sepudi, terutama para peternak sapi yang ada di Pulau Sepudi, bahwa tol laut yang selama ini mengangkut sapi dari wilayah Nusa Tenggara Barat (NTB) dan Nusa Tenggara Timur (NTT) ke Jakarta, bisa singgah ke Pulau Sepudi untuk juga mengangkut sapi-sapi yang ada di Pulau Sepudi dan dibawa ke Jakarta. Dengan begitu, nilai ekonomi sapi yang ada di Pulau Sepudi akan menjadi tinggi, sebab jarak distribusi dan penjualan terbilang pendek, dari peternak langsung kemudian dibawa ke Jakarta. Hal ini juga akan berdampak pada murahnya harga daging sapi di Jakarta dan kota-kota besar, sebab sapi yang dijual jaraknya lebih dekat daripada dari NTB dan NTT (Rasyidi, 2018).

\subsection{Wisata Bahari, Surga Tersembunyi di Ujung Madura}

Wilayah kepulauan Kabupaten Sumenep memiliki potensi wisata yang luar biasa menggiurkan. Potensi wisata tersebut terdiri dari pulau, pesisir pantai dan keindahan bawah laut yang memiliki terumbu karang dan spesies ikan hias yang menarik. Bahkan terdapat beberapa jenis ikan langka seperti napoleon ada di wilayah kepulauan Sapeken dan Kangayan. Malah ada wisata kesehatan, yang berada di Pulau Giliiyang, yang selama ini dikenal memiliki kandungan oksigen yang cukup tinggi.

Adapun wisata pantai yang paling terkenal di wilayah kepulauan Kabupaten Sumenep adalah di Pulau Gililabak, Kecamatan Talango dan Pantai 9 yang berada di Pulau Giligenting. Keberadaan wisata bahari di Pulau Giliiyang, Gililabak dan Giligenting menjadi semakin ramai dikunjungi warga dari berbagai wilayah di Indonesia, setelah adanya penerbangan komersil dari Bandara Juanda Surabaya ke Bandara Trunojoyo Sumenep setiap hari, dengan menggunakan pesawat Wings Air yang berkapasitas 70 penumpang (Sustono, 2018).

Wisatawan yang datang berkunjung ke lokasi wisata, di Kabupaten Sumenep yang terus bertambah. Menurut Sufiyanto, Kepala Dinas Pariwisata, Kebudayaan, Pemuda dan Olahraga Kabupaten Sumenep jumlah wisatawan yang datang ke Kabupaten Sumenep setiap tahun meningkat. Pada tahun 2016 misalnya, jumlah wisatawan yang datang sekira 854 ribu orang. Jumlah tersebut meningkat pada tahun 2017 menjadi satu juta lebih. Dan pada tahun 2018, hingga April saja sudah mencapai 371 ribu orang (Sufiyanto, 2018). 


\subsection{Tantangan Jejaring Transportasi}

Bagi wilayah kepulauan, transportasi udara dan laut menjadi satu keniscayaan sebagai sarana untuk menyambungkan pulau-pulau yang ada di satu wilayah, juga untuk menyambungkan pulau-pulau yang ada dengan wilayah lain yang merupakan bagi jaringan perekonomian dan mobilitas penduduk. Ketersediaan sarana transportasi udara dan laut menjadi kunci utama tersambungnya (conectivity) penduduk pulau yang satu dengan yang lain, juga dengan daerah kota di luar pulau-pulau tersebut.

Sarana transportasi di wilayah kepulauan Kabupaten Sumenep, Jawa Timur yang saat eksis adalah transportasi laut. Transportasi laut yang tersedia cukup beragam, mulai dari milik per orangan, perusahaan swasta maupun milik Badan Usaha Milik Daerah (BUMD) maupun Badan Usaha Milik Negara (BUMN) yaitu Pelni. Namun di antara sarana transportasi laut yang beroperasi, lebih banyak dimiliki oleh pihak per orangan (swasta), terutama trasnportasi yang menyambungkan pulau-pulau yang ada di satu wilayah kecamatan, maupun antar kecamatan yang ada di wilayah kepulauan. Transportasi yang disediakan oleh perorangan tersebut biasa digunakan untuk mengangkut orang dan barang-barang kebutuhan pokok, dari wilayah kota kecamatan ke pulau-pulau di sekitar kota kecamatan.

Seperti yang terjadi di wilayah kepulauan Sapeken, Kecamatan Sapeken, Kabupaten Sumenep, Jawa Timur. Di daerah tersebut, setiap hari puluhan perahu dan kapal motor (KM) yang terbuat dari kayu pergi dan pulang dari pulau-pulau yang ada di 11 desa di Kecamatan Sapeken. Warga yang diangkut oleh perahu dan kapal motor dari berbagai pulau tersebut datang ke Pulau Sapeken untuk belanja berbagai keperluan hidup maupun menjual hasil laut yang diperoleh. Setiap pagi, puluhan perahu dan kapal motor yang mengangkut warga dari berbagai pulau bersandar di dermaga Pulau Sapeken. Pada siang hari perahu dan kapal motor tersebut kembali ke pulau masing-masing. Dari saking padatnya perahu dan kapal motor yang bersandar, di Pulau Sapeken disediakan dua dermaga besar, supaya bisa menampung seluruh perahu dan kapal motor yang sandar setiap hari.

Hal yang sama juga terjadi di wilayah kepulauan Kecamatan Giligenting, Kabupaten Sumenep, Jawa Timur. Setiap hari ada sekitar ada 20 perahu yang beroperasi untuk mengangkut warga dari dan menuju ke Pulau Giligenting dari dan menuju Kota Sumenep, dengan jarak tempuh sekira satu jam perjalanan laut. Sama seperti di Kecamatan Sapeken, perahu dan kapal motor yang digunakan untuk mengangkut orang maupun barang merupakan milik per orangan (swasta). 
Hanya saja, kapal motor yang digunakan untuk mengangkut orang dan barang di Kecamatan Giligenting, berukuran lebih besar dari yang ada di wilayah kepulauan Sapeken. Begitu pula dengan operasional kapal motor di wilayah Giligenting berbeda dengan yang di wilayah Sapeken. Operasional kapal berlangsung sepanjang hari, dari pagi hingga sore hari.

Kondisi transportasi di kecamatan lain yang berada di wilayah kepulauan Kabupaten Sumenep, hampir sama dengan apa yang terjadi di Kecamatan Sapeken dan Kecamatan Giligenting, yang berbeda hanya di Kecamatan Raas dan Kecamatan Malasembu. Dua kecamatan di wilayah kepulauan tersebut dilayani oleh kapal mesin penyeberangan (KMP) milik perusahaan swasta dan tol laut.

Wilayah Kecamatan Raas, dilayani oleh dua unit kapal milik perusahaan Dharma Lautan Utama (DLU) yang menyambungkan wilayah kepulauan Raas dengan Kabupaten Sumenep, Madura dan Situbondo, Jawa Timur. Dua unit kapal milik DLU secara rutin mengangkut penumpang dan barang dari Raas, Sumenep dan Situbondo, sepekan dua kali pergi dan pulang. Tidak hanya sampai di Situbondo, dua kapal ini sangat membantu mobilitas warga Raas yang bekerja dan membuka usaha di Pulau Bali. Melalui kapal tersebut warga dari kepulauan Raas pergi dan pulang dari Pulau Bali melalui Pelabuhan Jangkar, Situbondo, Jawa Timur.

Sedangkan warga yang berada di kepulauan Masalembu dilayani oleh dua unit kapal perintis Sabuk Nusantara yang sekaligus berfungsi sebagai tol laut. Dengan kapal perintis Sabuk Nusantara warga yang berada di kepulauan Masalembu tersambung dengan Kota Surabaya dan Kota Sumenep. Rute pelayaran Sabuk Nusantara yang singgah di Masalembu bisa dari Surabaya, Masalembu dan Sumenep, bisa juga sebaliknya dari Sumenep, Masalembu dan ke Surabaya.

Lebih lengkap transportasinya lautnya adalah kepulauan Kangean dan kepulauan Sapeken. Pulau Kangean sebagai pulau terbesar yang berada di wilayah Kabupaten Sumenep memiliki dua kecamatan Arjasa dan Kangayan yang terdiri dari 28 desa. Transportasi menuju dan dari Pulau Kangean terbilang banyak. Hampir setiap hari kapal ada yang berlayar ke Pulau Kangean dari Pelabuhan Kalianget, Sumenep, Madura. Kapal yang melayani angkutan barang dan penumpang menuju Pulau Kangean terdiri dari Sumekar Line, perusahaan milik Pemerintah Kabupaten Sumenep yang berlayar sepekan tiga kali, setiap Selasa, Jumat dan Minggu. Selain kapal Sumekar Line, kapal lain yang melayani angkutan ke Pulau Kangean adalah kapal cepat Bahari Ekspres, milik perusahaan swasta yang berkantor pusat di 
Palembang, Sumatera Selatan. Kapal cepat ini secara khusus mengangkut penumpang dari Pelabuhan Kalianget ke Pulau Kangean tiga kali dalam satu pekan, yaitu setiap hari Senin, Kamis dan Sabtu.

Selain dua kapal tadi, kepulauan Kangean juga dilayani oleh Kapal Perintis Sabuk Nusantara, termasuk Kapal Perintis Caterine, yang biasa mengangkut penumpang dan barang dari dan menuju kepulauan Kangean. Selain kapal-kapal tersebut, untuk kepulauan Kangean terdapat beberapa kapal motor kayu berukuran besar yang biasanya mengangkut barang-barang kebutuhan bahan bangunan seperti semen, besi dan lain-lain yang diangkut dari Kalianget ke Pulau Kangean. Hal ini untuk mengurangi beban angkutan barang, terutama bahan bangunan dari kapal yang juga mengangkut penumpang.

Kepulauan lain yang juga tersambung dengan kota-kota di Madura, Bali dan Jawa adalah kepulauan Sapeken. Kapal yang melayani angkutan Sapeken adalah Kapal Perintis Sabuk Nusantara, Caterine, dan Kapal Sumekar. Kapal-kapal tersebut melayani angkutan penumpang dan barang dari dan menuju Sapeken ke Sumenep, Madura. Selain itu juga ke Banyuwangi, Jawa Timur dan Bali. Selain kapal tersebut, untuk angkutan barang dari Sapeken, terutama hasil perikanan biasanya dibawa ke Pulau Bali melalui Pelabuhan Singaraja Bali menggunakan kapal motor kayu milik para pengusaha ikan yang berada di Pulau Sapeken.

Sejauh ini, wilayah kepulauan yang tidak dilayani oleh kapal milik BUMD maupun BUMN adalah Pulau Sepudi. Angkutan penumpang dan barang dari dan menuju Pulau Sepudi yang terdiri dari dua kecamatan, yaitu Kecamatan Gayam dan Nonggunong hanya dilayani oleh satu kapal milik Dharma Lautan Utama (DLU), sisanya adalah kapal motor kayu berukuran besar milik per orangan, yang biasanya sandar di Pelabuhan Kalianget dan Pelabuhan Dungkek serta Pelabuhan Kalbut di Situbondo.

Padahal potensi peternakan sapi di Pulau Sepudi cukup besar. Sebab Sepudi merupakan wilayah penghasil sapi asli terbesar di Jawa Timur. Selama ini sapi-sapi yang ada Pulau Sepudi, dikirim ke berbagai wilayah di Indonesia, yaitu Sumenep, Madura melalui pelabuhan Dungkek, ke Jawa melalui Pelabuhan Kalbut, Situbondo, dan ke Banjarmasin, Kalimantan Selatan. Sapi-sapi tersebut setiap hari diangkut ke wilayah-wilayah tersebut menggunakan perahu motor kayu oleh para pengepul sapi dari Pulau Sepudi. 
Potensi peternakan sapi di Pulau Sepudi akan lebih besar dampaknya terhadap perekonomian peternak setempat jika tol laut yang secara khusus mengangkut ternak dari wilayah Nusa Tenggara Barat (NTB) dan Nusa Tenggara Timur (NTT) ke Jakarta, juga secara rutin singgah di Pulau Sepudi. Dari sisi pelabuhan, Pelabuhan Sepudi sangat siap untuk disinggahi kapal-kapal berukuran besar, sebab beberapa tahun lalu di Sepudi baru saja selesai dibangun sebuah dermaga berukuran besar yang menggunakan APBD Jawa Timur. Salah satu persoalan yang perlu diperbaiki adalah rute pelayaran Kapal Perintis Sabuk Nusantara yang juga menjadi tol laut. Sejauh ini kapal-kapal perintis yang beroperasi jalur dan rutenya cukup jauh. Sehingga untuk melayani satu daerah kepulauan juga jaraknya cukup lama. Rata-rata untuk setiap kepulauan, seperti Kepulauan Sapeken dilayani oleh kapal perintis setiap 10 hari sekali. Hal tersebut kurang membantu kebutuhan mobilitas barang dan orang dari dan menuju kotakota besar di Jawa dan Madura. Jalur yang selama ini menghubungkan pulau-pulau di dalam wilayah Kabupaten Sumenep tidak meningkatkan mobilitas perekonomian warga, sebab tidak ada komoditas yang diangkut oleh kapal tersebut dari satu pulau ke pulau lain. Seperti misalnya dari Masalembu ke Kangean dan Sapeken (Sahril, 2018).

Sebagai catatan, dari sejumlah kapal yang beroperasi di wilayah kepulauan Kabupaten Sumenep, Jawa Timur, meskinya rute pelayaran tidak perlu jauh dan panjang. Rute yang jauh dan panjang juga menyebabkan operasional kapal seperti bahan bakar minyak (BBM) cukup tinggi, jika rutenya diperpendek akan mengurangi beban operasional, dan mesin kapal lebih awet sebab ada banyak waktu istirahat saat bersandar di dermaga.

Untuk meningkatkan daya ungkit (leverage) terhadap perekonomian warga kepulauan yang perlu dilakukan adalah penataan ulang (rearrangement) rute kapal yang selama ini telah berjalan. Jika dihitung, ada empat kapal perintis yang selama ini melayani angkutan penumpang dan barang di wilayah kepulauan Kabupaten Sumenep. Kapal-kapal tersebut adalah Kapal Perintis Sabuk Nusantara 27, Kapal Perintis Maumere, Kapal Perintis Caterine, dan Kapal Perintis Sabuk Nusantara 56. Dua kapal yang ada yaitu Sabuk Nusantara 27 dan 56 rutin beroperasi di jalur Surabaya, Masalembu, Kalianget, Kangean, Sapeken dan Banyuwangi. Sedangkan dua lainnya, yaitu Caterine dan Maumere melayani hingga Bali dan Nusa Tenggara Timur (NTT).

Dua kapal Sabuk Nusantara yang secara khusus beroperasi di wilayah Kabupaten Sumenep difokuskan untuk melayani angkutan penduduk dan barang. 
Misalnya, Sabuk Nusantara 27 dikhususnya untuk melayani angkutan penumpang dan barang dari Masalembu ke Surabaya. Maka dalam satu pekan, warga di kepulauan Masalembu akan dilayani oleh tiga kali kapal yang akan mengangkut barang dan penumpang dari Masalembu ke Surabaya dan sebaliknya. Hal ini akan memberi kepastian jadwal kapal yang berangkat dari dan ke Pulau Masalembu-Surabaya. Maka orang di Pulau Masalembu atau orang yang di Surabaya akan terbiasa, atau terpola merancang kepergian dengan kapal yang ada (Darul Hasyim, 2018).

Jauh lebih penting dari itu, kepastian adanya kapal tiga kali dalam satu pekan akan membuat warga berusaha menyesuaikan untuk mengumpulkan barang-barang hasil laut yang akan dijual ke Surabaya. Dengan begitu geliat ekonomi warga kepulauan Masalembu akan lebih terasa. Sebab tidak hanya akan membawa barang untuk dijual ke Surabaya, sebaliknya mereka akan lebih mudah untuk berbelanja barang kebutuhan untuk dijual kembali di Masalembu.

Begitu pula dengan warga di kepulauan Sapeken yang selama ini dilayani kapal dalam hitungan sepekan sekali, jika Sabuk Nusantara 56 dikhususkan untuk melayani angkutan penumpang dan barang dari Sapeken ke Banyuwangi, maka dalam satu pekan warga bisa dilayani hingga tiga kali. Arus barang hasil laut yang akan dijual ke Jawa melalui Banyuwangi dari Sapeken akan semakin banyak, pedagang ikan akan mengalihkan angkutan barangnya dari perahu motor kayu ke kapal perintis, sebab biaya angkutnya lebih murah (Musfirah, 2018).

Dampaknya, arus barang yang dijual dari luar pulau-pulau tersebut ke kotakota besar akan semakin sering. Begitu pula sebaliknya, barang-barang kebutuhan makanan, bangunan dan keperluan hidup lain yang berasal dari kota-kota di Jawa dan Madura akan semakin banyak dan sering dikirim ke pulau-pulau tersebut. Secara ekonomi ini berdampak positif.

Jika hal tersebut terwujud, akan ada tiga asas yang terpenuhi di dalam pelayanan pelayaran bagi warga kepulauan, yaitu asas kepastian jadwal keberangkatan (certainty), setiap hari apa saja kapal akan berangkat dan datang. Berikutnya adalah asas penghematan operasional kapal (efesiensi). Dan terakhir adalah asas pemeliharan dan perawatan mesin kapal lebih terjamin.

\subsection{Kebutuhan Transportasi Udara}

Besarnya jumlah penduduk di kepulauan Kangean dan sekitarnya yang terdiri dari tiga kecamatan, yaitu Arjasa, Kangayan dan Sapeken kurang lebih sekira 120 ribu 
jiwa menjadi satu potensi tersendiri yang dapat meningkatkan perekonomian daerah. Di tiga kecamatan tersebut, pusat usaha dan bisnis terkonsentrasi di Arjasa dan Sapeken. Pulau Kangean merupakan pulau yang paling besar dan paling luas di antara gugusan kepulauan yang berada di wilayah Kabupaten Sumenep (Nurwahyudi, 2018).

Selain memiliki potensi demografi yang memadai, warga kepulauan Kangean juga memiliki mobilitas yang cukup tinggi. Sehingga kebutuhan transportasi yang selama ini hanya dilayani dengan jalur laut dinilai kurang memadai. Hal tersebut disampaikan oleh Saifuddin, tokoh masyarakat kepulauan Kangean. Menurut Saifuddin, warga di kepulauan Kangean hampir 20 persen bekerja di luar pulau, sebagian ada yang di kota-kota besar di Indonesia, seperti Banjarmasin, Kalimantan Selatan, dan Jakarta. Sedangkan sebagian lagi menjadi tenaga kerja Indonesia di luar negeri, seperti Malaysia, Singapura dan Arab Saudi (Safrudin, 2018). Jumlah tersebut akan lebih besar jika dihitung dengan para mahasiswa dan pelajar yang menuntut ilmu di kota-kota di Jawa seperti Surabaya, Malang dan Yogyakarta.

Transportasi laut yang selama ini dilayani oleh dua kapal yaitu Dharma Bakti Sumekar dan Bahari Ekspres selalu dipadati penumpang dari dan menuju kepulauan Kangean-Sumenep, meski masing-masing kapal beroperasi setiap dua hari sekali. Artinya setiap hari ada kapal yang beroperasi melayani angkutan penumpang dan barang dari Pelabuhan Kalianget Sumenep ke kepulauan Kangean, kecuali hari Rabu. Belum lagi kapal perintis yang dioperasikan oleh Pelni yang sekaligus sebagai tol laut. Jika ada satu kapal yang tidak beroperasi karena ada kerusakan atau perbaikan (docking) bisa dipastikan, kapal yang berangkat sehari setelahnya akan semakin penuh (Rahman, 2018).

Daya beli masyarakat kepulauan Kangean relatif tinggi. Hal ini bisa dilihat dari rumah-rumah warga Pulau Kangean yang cukup bagus. Bentuk, ukuran dan bahan bangunan yang digunakan juga sama dengan rumah-rumah di Pulau Jawa. Begitu pula dengan tarif kapal laut yang selama ini digunakan, tetap terjangkau. Bahkan, kapal cepat dengan harga tiket Rp 250 ribu tetap dibeli oleh warga Pulau Kangean. Hal ini menunjukkan bahwa warga kepulauan Kangean sangat siap dan berpotensi untuk dilayani transportasi udara (Hasyim, 2018).

\section{Penutup}

Ketersambungan (connectivity) dan aksesibilitas menjadi kata kunci, sekaligus syarat bagi kemajuan dan perkembangan daerah kepulauan yang memiliki 
potensi kemaritiman yang luar biasa besar. Ketersambungan (connectivity) dan akses yang dimaksud adalah, ketersambungan antara wilayah kepulauan tersebut dengan kota-kota besar yang lokasinya berdekatan. Bagi wilayah kepulauan yang berada di dalam pemerintahan Kabupaten Sumenep, Jawa Timur ketersambungan yang diharapkan adalah ketersambungan dengan kota-kota besar seperti Bali, Jawa dan Madura. Ketersambungan bisa melalui jalur laut yang memiliki jarak tempuh semakin pendek dan lebih sering, maupun ketersambungan melalui jalur udara. Dengan begitu, arus mobilitas barang dan warga akan semakin tinggi, dan selanjutnya akan memicu percepatan pertumbuhan perekonomian warga kepulauan yang memiliki potensi perikanan dan kelautan yang luar biasa besar (big fish, is big economic potensial).

Sembari menunggu ketersambungan lewat udara, langkah pemerintah pusat melalui Kementerian Perhubungan, Direktorat Jenderal Hubungan Lalu Lintas Laut, Pemerintah Propinsi Jawa Timur, dan Pemerintah Kabupaten Sumenep dengan menambah armada kapal angkutan penumpang dan barang di wilayah Kabupaten Sumenep dengan Kapal Sabuk Nusantara 115 yang sudah beroperasi sejak Idul Fitri tahun 2018, dan kapal Sumekar yang sedang dalam proses pembuatan oleh PT Adi Luhung di Surabaya, perlu diapresiasi. Sebab akan semakin membuat mobilitas barang dan manusia di wilayah kepulauan semakin tinggi.

Keberadaan pihak swasta yang bergerak di bidang transportasi perlu semakin dibuka, dengan begitu akan semakin memperkuat ketersambungan (connectivity) wilayah kepulauan. Misalnya Kapal Bahari Ekspres yang selama ini hanya melayani rute Sumenep-Kangean, diharapkan akan membuka rute baru dalam melayani angkutan penumpang, misalnya rute pendek, Sumenep-Sepudi yang selama ini masih dilayani oleh kapal motor kayu khusus angkutan penumpang.

Selain itu, perusahaan minyak dan gas (migas) yang telah beroperasi di wilayah kepulauan Sumenep perlu dimaksimalkan keberadaannya. Salah satunya dengan menambahkan fasilitas angkutan untuk penumpang, bagi kapal-kapal yang selama ini hanya mengangkut logistik perusahaan. Kapal-kapal tersebut juga mengangkut penumpang ke wilayah kepulauan yang terdekat dengan tempat kegiatan eksplorasi maupun produksi perusahaan, tentu saja dengan memodifikasi fasilitas di atas kapal, sehingga layak untuk mengangkut penumpang. Sebagai contoh, upaya PT Kangean Energy Indonesia (KEI) yang meminjamkan lapangan terbangnya untuk keperluan penerbangan umum sangat positif. 


\section{Referensi}

Bisri, M (2013, 28 Maret). Sumenep Dapat Dana Bagi Hasil Migas Blok Maleo. Dikutip dari www.tempo.co.

Ern. (2013, 8 Maret). Sumenep Miliki Potensi Kelautan Berkualitas. Dikutip dari www.kominfo.jatimprov.go.id.

Faqih, A. (2014). Prospek Pengembangan Potensi Sumberdaya Kelautan Madura Kepulauan. Malang: Universitas Brawijaya Press (UB Press).

Hidayaturrahman, M. (2017). Sumber Daya Alam Migas dan Ancaman Kutukan Bagi Warga Madura. Artikel Seminar Internasional Islamic Research Forum (IIRF) IAIN Palangkaraya, Kalimantan Tengah, 27-28 Nopember 2017.

Junita, N, et al. (2017). Analisis Aksesibilitas Infrastruktur Pedesaan di Kota Singkawang Provinsi Kalimantan Barat. Dikutip dari https://media.neliti.com.

Kuswati, A \& Herawati. (2017). Connectivity of Antarmoda Transportation In Tulungagung District. Jurnal Transportasi Multimoda, 15 (01), (55).

Magribi, L \& Suhardjo, A. (2004). Aksesibilitas dan Pengaruhnya Terhadap Pembangunan di Perdesaan: Konsep Model Sustainable Accessibility Pada Kawasan Perdesaan di Propinsi Sulawesi Tenggara. Jurnal Transportasi, 4 (2), (151).

Sosilawati, et al. (2017). Sinkronikasi Program dan Pembiayaan Pembangunan Jangka Pendek 2018-2020, Keterpaduan Pengembangan Kawasan Dengan Infrastruktur Pekerjaan Umum dan Perumahan Rakyat: Pulau Bali dan Kepulauan Nusa Tenggara. Jakarta: Pusat Pemograman dan Evaluasi Keterpaduan Infrastruktur PUPR, Badan Pengembangan Infrastruktur Wilayah, Kementerian Pekerjaan Umum dan Perumahan Rakyat.

Sutaryo, et al. (2015). Membangun Kedaulatan Bangsa Berdasarkan Nilai-Nilai Pancasila: Pemberdayaan Masyarakat Dalam Kawasan Terluar, Terdepan, dan Tertinggal (3T). Yogyakarta: Pusat Studi Pancasila, Universitas Gadjah Mada. Suryana, A, ed. (2018). Pembangunan Daerah Kepulauan: Studi Kasus Provinsi Kepulauan Riau dan Provinsi Maluku Utara. Jakarta: Yayasan Pustaka Obor Indonesia. BPS Sumenep. (2017). Kabupaten Sumenep Dalam Angka. Sumenep: BPS.

Wahdiniwaty, R. (2011). Aksesibilitas Wisata Pada Kota Metropolitan di Negara Berkembang (Suatu Survey di Wilayah Bandung Raya). Majalah Ilmiah UNIKOM, 11 (2), (201).

\section{Wawancara}

Hasyim. (2018, 7 Juni). Mahasiswa asal kepulauan Kangean.

Hasyim, Darul. (2018, 5 Juni). Anggota DPRD Sumenep asal Masalembu.

Kahir, Abd. (2018, 6 Juni). Kabag ESDM Sekda Kabupaten Sumenep.

Musfirah. 2018, 10 Juni). Pengusaha ikan beku dan kering Sapeken.

Nurwahyudi, Yayak. (2018, 6 Juni). Kepala Bappeda Kabupaten Sumenep.

Rahman. (2018, 10 Juni). Warga Pulau Kangean di rumahnya.

Rasyidi, Hambali. (2018, 1 Juni). Tokoh masyarakat Pulau Sepudi. 
Safrudin. (2018, 4 Juni). Ketua Komunitas Warga Kepulauan (KWK).

Sahril. (2018, 5 Juni) Dosen Fakultas Ekonomi dan Bisnis Universitas Wiraraja.

Sufiyanto. (2018, 7 Juni). Kadis Parbudpora Kabupaten Sumenep.

Sustono. (2018, 7 Juni). Kadis Perhubungan Kabupaten Sumenep.

Wawang. (2018, 3 Juni). Pengusaha ikan kerapu kepulauan Sapeken 